\title{
EFEKTIVITAS STRAIN BRADYRHIZOBIUM JAPONICUM YANG DIISOLASI DARI BEBERAPA LOKASI DI ENDE TERHADAP PEMBENTUKAN NODUL DAN PENAMBATAN NITROGEN PADA TANAMAN KEDELAI ( GLYCINE MAX L. )
}

\author{
Kristina Erniyani \\ Dosen Fakultas Pertanian Universitas Flores \\ Jl. Sam Ratulangi No.1 Ende-Flores, NTT
}

\begin{abstract}
Bacteria Bradyrhizobium spp. Form nodules on soybean plants, bind nitrogen from the air and menjadikanya freely available to plants. Amount of nitrogen fixed depends on the ability of a strain to form nodules, nodule effectiveness and environmental conditions. On land - land that had been planted with soybeans, inoculation with Bradyrhizobium bacteria are often not required.

To test these lands in the district of Ende, NTT has conducted an experiment a factor in the design of Randomized Complete with nine treatment groups. The treatment consists of (i) inoculation with the soybean crop in the ground former Ekoae (R1), (ii) inokuklasi dengantanah former soybean plants in Ndona (R2), (iii) inoculation of soybean plants with the soil used in Flores (R3), (iv) bradyrhisobium isolates from soybean nodules in Ekoae (R4), (v) Bradyrhisobium isolates from nodules of soybean plants in Ndona (R5), (vi) Bradyrhisobium isolates from nodules of soybean plants at Flores (R6), (vii) a commercial inoculant legin (L ), (viii) fertilizer nitrogen (N), and (ix) Control (K). all treatment was repeated 4 times. Land used in these experiments is the land of Ndona.The experiment was carried out since 2009 until February 2010 desembar greenhouse majoring in biology, mathematics and science faculty, Udayana University.

The highest percentage of effective nodules on the treatment Bradyrhisobium isolates from soybean nodules in Ndona (R5). Total nitrogen levels at the age of 45 HST is the highest in soybean plants that received $100 \mathrm{~kg}$ ha-1urea and soybeans that have a diisolat Bradyrhisobium inoculation of soybean nodules in Ndona (R5). Efficiency and levels of symbiotic nitrogen fixation results obtained highest in soybean plants that received an inoculation Bradyrhisobium diisolat from soybean nodules in Ndona (R5).Oven dry weight of plants that form the age of 45 HST on all isolates are equivalent to oven dry weight of plants at the fertilization of $100 \mathrm{~kg}$ ha- 1 urea.

The results showed that the land - the land of Ekoae, Ndona and Flores have high Bradyrhisobium contain bacteria. Bacteria Bradyrhisobium sp. Most numerous in the isolates from soybean nodules in Ndona (R5) the most efficient form effective nodules is $82.26 \%$ and as high as the $0.52 \% \mathrm{~N}$ fixate. These results indicate that isolates from Ndona Bradyrhisobium been able to form effective nodules on soybeans grown in soil from Ndona. The results also indicate inoculation with a commercial inoculant dioeroleh not on land - land planted with soybeans used
\end{abstract}

\section{Kata Kunci : Bradyrhisobium sp., penambat nitrogen, tanaman kedelai, tanah dari Ende}




\section{PENDAHULUAN}

Kacang - kacangan merupakan sumber protein nabati bagi manusia maupun ternak. Tanaman kacang kacangan mampu memenuhi nitrogennya melalui peningkatan nitrogen dari udara bebas oleh bakteri penambat nitrogen yang bersimbiosis dengannya. Penggunaan bakteri penambat nitrogen sebagai pemasok nitrogen pada tanaman kacang kacangan memiliki keunggulan dibandingkan dengan pupuk nitrogen anorganik. Keunggulannya ialah membantu proses pelarutan hara, menekan pencemaran lingkungan, meningkatkan kesuburan dan produktivitas tanah, efisiensi penggunaan pupuk dan relative murah ( Simanungkalit dkk. 2006).

Simbiosis Bradyrhisobium sp. Dan tanaman kacang - kacangan berawal dari infeksi jaringan akar legume oleh Bradyrhisobium sp. Infeksi terjadi karena adanya flafonoid yang dihasilkan tanaman inang yang menarik Bradyrhisobium sp. K3e akar untuk membentuk nodul ( Rhijin dan Vanderleyden, 1995 ; kambara, 2008). selain flafonoid, suhu ( Rao, 1994), air tanah ( Jutomo, 1981 ) juga mempengaruhi infeksi akar oleh Bradyrhisobium sp.

Factor penentu keberhasilan penambatan nitrogen dari udara oleh Bradyrhisobium sp yaitu keserasian strain Bradyrhisobium sp. Dengan inang, mampu berkompetisi antaran Bradyrhisobium sp. Dengan mikroorganisme lain ( Simanungkalit dkk. 2006 ), kemampuan inang untuk menyediakan nutrisi bagi Bradyrhisobium sp. Yang bersimbiosis dengannya ( Atkins, 1987 dalam Arimurti dkk. 2000 ). Factor lingkungan juga berpengaruh pada keberhasilan penambatan nitrogen antara lain : ketersediaan hara makro dan mikro, kelembapan tanah, $\mathrm{pH}$ tanah, suhu dan cahaya mata hari( Freire, 1984 ). Gray dan Williams 1971) menyatakan bahwa perkembangan Bradyrhisobium sp. dalam tanah apabila ada tanaman legum dan populasi Bradyrhisobium sp menurun jika tidak ada tanaman legum sehingga bakteri Bradyrhisobium sp. Akan mati dalam waktu \pm 10 tahun.

Pertumbuhan tanaman kedelai yang diinokulasi dengan isolate Bradyrhisobium dari tanaman kedelai mempunyai pertumbuhan lebih baik dari pada menggunakan isolate Bradyrhisobium dari tanaman kacang hijau ( Vigna radiate L. ) ( Purwaningsih, 2005b). Hasil penelitian Muksin (2006 )menunjukan bahwa inokulasi dengan tanah bekas tanaman kedelai tidak efektif meningkatkan hasil tanamn kedelai walaupun jumlah bakteri Bradyrhisobium tergolong tinggi $\left(11,7 \times 10^{5}\right.$ rhizobia g $^{-1}$ tanah $)$, sehingga perlu dilakukan penelitian dengan mengisolasi Bradyrhisobium dari daerah asal menjadi biakan murni dan mengevaluasi efektivitas simbiosis Bradyrhisobium yang digunakan dalam menambat nitrogen sehingga meningkatkan produktivitas tanaman kedelai.

Produksi tanaman kedelai di kabupaten Ende pada tahun 2007 tergolong rendah yaitu 13 ton dengan luas panen 23 ha atau $565 \mathrm{~kg} / \mathrm{ha}$ (BPS Kabupaten Ende, 2008). Penggunaan inokulan komersial belum pernah dilakukan sehingga pembentukan nodul terjadi oleh Bradyrhisobium alami. Kecamatan ndona merupakan salah satu daerah yang berpotensi untuk pengembangan tanaman kedelai dan pemerintah Kabupaten Ende menggalakan penanaman tanaman kedelai di Ndona. 
Hasil studi lapang menunjukan bahwa tanaman kedelai di Ndona mempunyai nodul dengan diameter paling besar dari nodul tanaman kedelai di Ekoae dan Kelimutu yaitu $3-5$ mm. nodul tanaman kedelai dari Ndona berwarna merah dan tidak terdapat nodul yang rusak ( Lampiran 3). Islami dan Utomo (1995) menjelaskan nodul yang terbentuk tidak sama efektifitasnya. Nodul yang ukuran lebih kecil dari normal umumnya disebapkan oleh infeksi bakteri Bradyrhisobium yang tidak efektif. Lebih lanjut Havlin et al. (1999) menyatakan nodul yang efektif cenderung besar, bentuk bulqat lonjong (elongated) dengan ukuran 2 4 x $4-8 \mathrm{~mm}$ dan berkelompok pada akar primer, berwarnah merah muda sampai merah. Nodul tidak efektif berukuran lebih kecil, menyebar di seluruh akar dan berwarnah putih pucat. Volume relative jaringan bakteroid ( 16 $\%$ - $50 \%$ dari berat kering nodul ) jauh lebih besar pada nodul yang efektif dibandingkan pada nodul tidak efektif. Warnah putih pucat dari nodul tidak efektif disebapkan kekurangan kandungan leghemoglobin leguminosae hemoglobin ). Menurut Rao( 1994) nodul yang efektif adalah yang berukuran besar, jika jaringan nodul dibelah dua pada bagian tengah kelihatan berwarna merah karena mengandung leghemoglobin. Nodul yang efektif cenderung mengumpul pada pangkal akar dan daerah sekitarnya.

Berdasarkan ulasan diatas maka masalah yang hendak dikaji : Bagaimana potensi bakteri $B$. japonicum di dalam tanah pada beberapa lokasi di Ende?, Bagaimana efisiensi strain $B$. japonicum yang di isolasi dari Ende untuk membentuk nodul efektif pada tanaman kedelai?, Bagaimana efisiensi strain $B$. japonicum yang diisolasi dari Ende untuk menambat nitrogen pada tanaman kedelai?.dan yang menjadi tujuan dalam penelitian ini adalah : Untuk mengetahui potensi bakteri $B$. japonicum di dalam tanah dari beberapa lokasi di Ende, Untuk mengetahui efisiensi strain $B$. japonicum yang diisolasi dari Ende untuk membentuk nodul pada tanaman kedelai, Untuk mengetahui efisiensi strain B. japonicum yang diisolasi dari Ende untuk menambat nitrogen pada tanaman kedelai. Adapun manfaat dari penelitian ini adalah sebagai pengembangan ilmu pengetahuan khususnya dalam fiksasi nitrogen dari simbiosis kedelai dengan Bradyrhisobium sp. Dan bagi petani yaitu sebagai bahan dasar pembuatan inokulan Bradyrhisobium sp.

\section{METODE}

Penelitian ini dilaksanakan di lab. Mikrobiologi Jurusan Biologi Fakultas MIPA Universitas Udayana. Waktu penelitian dimulai Desember 2009 sampai Maret 2010. Penelitian ini menggunakan Rancangan Acak Kelompok Lengkap(RAKL) dengan perlakuan : R1 = Inokulasi dengan tanah bekas tanaman kedelai di Ende, R2 = Inokulasi dengan tanah bekas tanaman kedelai di Ndona, R3 = Inokulasi dengan tanah bekas tanaman kedelai di Kelimutu, R4 = isolat Bradyrhisobium dari nodul tanaman kedelai di Ekoae, R5 = isolat Bradyrhisobium dari nodul tanaman kedelai di Ndona, R6 = isolat Bradyrhisobium dari nodul tanaman kedelai di Kelimutu, $\mathrm{L}=$ inokulan komersial Legin (30 gram / $8 \mathrm{~kg}$ benih) atau tanpa melalui perbanyakan dalam YMB, $\mathrm{N}=$ pemupukan Nitrogen (dosis $100 \mathrm{~kg} \mathrm{ha}^{-1}$ urea) $\mathrm{K}$ = tanpa inokulan dan tanpa pemupukan

Bahan yang digunakan antara lain : tanah bekas tanaman kedelai, nodul kedelai, media Yeast Mannitol 
Borth dan Yeast Manitol Agar, NaCL, aquades, congo red, alcohol $95 \%$, benih kedelai, tisu, kapas, alumanium foil, inokulan komersial, pupuk urea, KCL, TSP, dan ammonium molybdate.

Alat yang digunakan antara lain : tabung reaksi, shaker atau vortex, pipet, petridish,baker glass, ${ }_{\mathrm{p}} \mathrm{H}$ meter, jarum ose, spatula, laminar flow, autoclave, oven, kulkas, timbangan, pot, mikroskop Olympus, gelas objek, ayakan, $(\mathrm{D}=0,02 \mathrm{~cm})$, stirrer, Bunsen, hands prayer, pot plastic dan skop.

\section{Pelaksanaban percobaab meliputi}

\section{Isolasi Bradyrhisobium}

Bradyrhisobium diisolsi dari nodul kedelai dan dari tanah bekas pemanenan kedelai untuk mendapatkan jumlah bakteri dalam tanah. Masing - masing diambil dari tiga lokasi di Ende dengan ketinggian yang berbeda : di ekoae ( Wewaria ) dengan ketinggian $\pm 6 \mathrm{~m}$ dpl, Ndona \pm $74 \mathrm{~m}$ dpl, dan kelimutu \pm 1.248 $\mathrm{m} \mathrm{dpl}$

2. Persiapan mediah tanam

Media tanam yang digunakan adalah tanah yang berasal dari Ndona. Tanah dikeringkan dan dibersikan dari sisa - sisa tanaman dan kotoran lain, dihancurkan dan di ayak. Dan dimasukan kedalam pot yang berdiameter $10 \mathrm{~cm}$.

3. Pemupukan

TSP, KCL dan ammonium molybdate diberikan sebagai pupuk dasar pada saat tanam. Dasis TSP $50 \mathrm{~kg} \mathrm{ha}^{-1}$, KCL 50 $\mathrm{kg} \mathrm{ha}^{-1}$ dan ammonium molybdate $1 \mathrm{~kg} \mathrm{ha}^{-1}$.

4. Persiapan benih dan inokulasi

Benih yang digunakan adalah kedelai varietas anjasmoro, dipilih berdasarkan bentuk dan ukurannya sehingga seragam.
Steril dengan alcohol $70 \%$ selama 15 menit, dan dicuci dengan air steril sebanyak 5 kali.

5. Penanaman

Benih ditanam dalam pot sedalam $1-2 \mathrm{~cm}$ dari permukaan tanah dan setiap pot terdapat $3-4$ benih, penanaman dilakukan pada sore hari dan ditutup dengan lapisan tipis tanah guna menjaga kelembaban.

Panen

Panen dilakukan ketika tanaman pada stadia bunga penuh (reproduktif 2) atau pada 45 hst. (Blanco et al. 2008). Panen dilakukan secara bersamaan untuk setiap per;lakuan.

\section{Variable pengamatan}

1. Jumlah total populasi bakteri Bradyrhisobium ( bakteri $/ \mathrm{g}^{-1}$ ) Total populasi ( bakteri $\mathrm{g}^{-1}$ ) $=$ jumlah koloni $\mathrm{x}$ factor pengenceran

tanah /nodul

Berat kering contoh

2. Luas daun per tanaman $\left(\mathrm{cm}^{2}\right)$

Diukur dengan metode planimetri, dimana luas daun didapat dari $\mathrm{P} \quad \mathrm{x} \quad \mathrm{L} \quad \mathrm{x} \quad \mathrm{K}$ (konstanta) dan dihitung saat umur 15,30 dan 45 hst.

3. Jumlah total nodum

Menghitung jumlah nodul pada akar tanaman setelah dibersihkan dari tanah. Nodul adalah bintil akar yang terdapat pada akar tanaman pada saat panen.

4. Jumlah nodum efektif

Menghitung nodul efektif pada setip perlakuan. Pengamatan nodul efektif adalah dengan membelah masing - masing nodul yang yang efektif 
berwarnah pink atau kemerahan sedangkan yang kurang efektif berwarnah putih dan skor warnah nodul sebagai berikut :

4 : nodul berwarnah red/ merah

3 : nodul berwarnah pink

2 : nodul berwarnah putih

1 : nodul berwarnah coklat atau hijau

5. Efisiensi jumlah pembentukan nodul efektif

Efisiensi pembentukan nodul efektif adalah kemampuan relatif bakteri membentuk nodul efektif.

Persentase

bradyrhizobium sp. Mampu membentuk nodul efektif dihitung dengan mengklasifikasikan nodul berdasarkan skor warnah nodul, dimana jumlah nodul efektif dibagi jumlah nodul terbentuk dikali $100 \%$.

6. Berat kering nodul efektif Nodul efektif dioven pada suhu $65^{\circ} \mathrm{c}$ sampai beratnya konstan

7. Diameter nodul

Mengukur 10 nodul dari setiap perlakuan. Mengukur dengan menggunakan jangka sorong.

8. Berat kering tanaman tanpa nodul

Tanaman tanpa nodul timbang untuk memperoleh berat segar kemudian di oven pada suhu $65^{\circ} \mathrm{c}$ sampai beratnya konstan.

9. Kadar N tanaman

Diambil bagian diatas tanaman dari masing - masing perlakuan dianalisis di Lab. Dengan menggunakan metode kjeldahl dikali berat kering tanaman bagian atas $\operatorname{tanah}\left(\mathrm{g} \tan ^{-1}\right)$ (Yaman dan Cinosy, 1996 dalam Ogutcu et al. 2008)

10. $\mathrm{N}$ fiksasi

Kadar N pada tanaman yang diinokulasi Bradyrhizobium dengan kadar $\mathrm{N}$ pada perlakun pemupukan nitrogen dikali 100\% (Beck et al. 1993 dalam Ogutcu et al. 2008).

11. Efisiensi simbiosis

\section{Analisis data}

Data hasil pengamatan dianalisis dengan analisis sidik ragam sesuai dengan rancangan yang digunakan apabila perlakuan menunjukan pengaruh nyata terhadap variable yang diamati, maka dilanjutkan dengan uji Duncan taraf $5 \%$. Data yang menunjukan nilai koefisien keragaman diatas $20 \%$ dilakukan transformasi untuk menstabilkan varians ( Gomez, dan Gomez, 1995).

\section{HASIL DAN PEMBAHASAN}

1. Jumlah Bakteri Bradyrhizobium sp. Dalam Beberapa Sumber Inokulum

Jumlah bakteri Bradyrhizobium sp. Paling banyak ditemukan pada biakan yang berasal dari nodul tanaman kedelai di Ndona yaitu $15 \times 10^{6}$ bakteri dan terendah pada inokulan komersial ligin dengan jumlah koloni 4,8 x $10^{4}$ bakteri (Tabel 5.1) 
Tabel 5.1. Pengaruh Perlakuan Terhadap jumlah koloni bakteri

\begin{tabular}{llllc}
\hline & \multicolumn{1}{c}{ Inokulan } & \multicolumn{3}{c}{ Jumlah Bakteri gram $^{-1}$} \\
\cline { 3 - 6 } No & \multicolumn{2}{c}{$10^{4}$} & $10^{5}$ & $10^{6}$ \\
\hline 1 & Pada tanah bekas tanaman kedelai di Ekoae & - & $\mathbf{7}$ & - \\
2 & Pada tanah bekas tanaman kedelai di Ndona & - & $\mathbf{4}$ & - \\
3 & Pada tanah bekas tanaman kedelai di & - & $\mathbf{3}$ & - \\
& kelimutu & - & - & $\mathbf{1 0 , 8}$ \\
4 & Pada nodul tanaman kedelai di ekoae & - & - & $\mathbf{1 5}$ \\
5 & Pada nodul tanaman kedelai di Ndona & - & - & $\mathbf{7 , 8}$ \\
6 & Pada Nodul Tanaman kedelai di Kelimutu & - & $\mathbf{4 , 8}$ & - \\
7 & Pada Inokulan Komersial Legin & & & \\
\hline
\end{tabular}

2. Pengaruh Perlakuan Terhadap Variabel Pengamatan Hasil analisis statistic menunjukan bahwa perlakuan yang diberikan pada tanaman kedelai berpengaruh sangat nyata $(\mathrm{P}>0,01)$ terhadap luas daun pertanaman umur $45 \mathrm{hst}$, total nodul terbentuk, jumlah nodul efektif efisiensi pembentukan nodul diameter nodul, berat segar nodul, berat kering nodul kadar $\mathrm{N}$ tanaman, $\mathrm{N}$ fiksasi dan efisiensi simbiosis. Hasil analisis statistika yang bderpengaruh nyata $(<0,05)$ terhadap tinggi tanaman $15 \mathrm{hst}$, luas daun pertanaman 30 hst, berat kering tanaman dan berpengaruh tidak nyata $(\geq 0,05)$ terhadap variable lainnya (Tabel 5.2)

Tabel 5.2. Pengaruh perlakuan terhadap variabel yang diamati

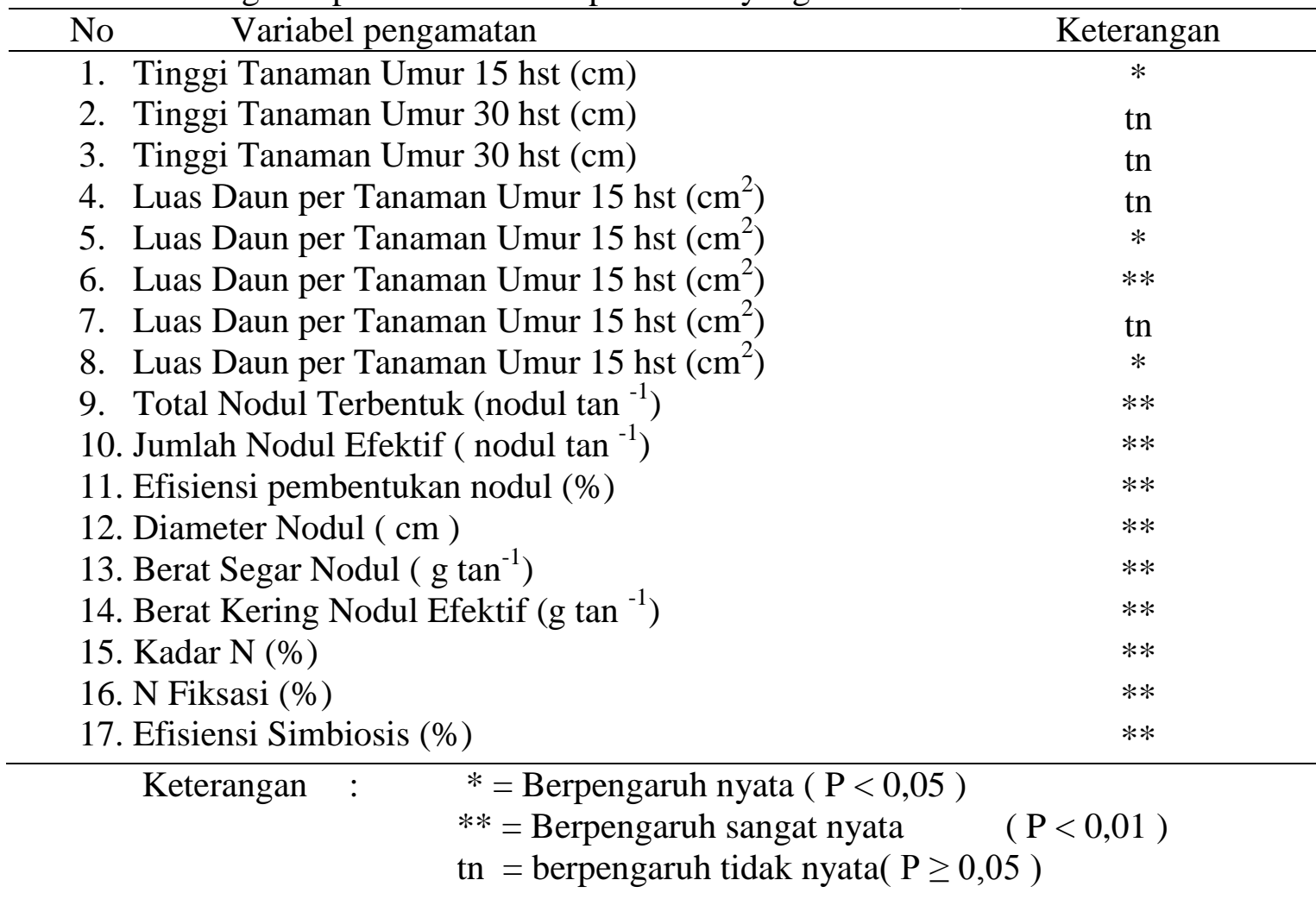


3. Tinggi Tanaman Umur 15, 30, dan 45 hst

Hasil penelitian menunjukan bahwa tinggi tanaman umur 15 hst tertinggi pada perlakuan pemupukan nitrogen $(\mathrm{N})$ (Tabel
5.3). Tinggi tanaman kemudian meningkat tetapi pada umur 30 dan 45 hst tidak ditemukan pengaruh yang nyata antara perlakuan (Tabel 5.3).

(Tabel 5.3). Pengaruh perlakuan terhadap tinggi tanaman umur 15, 30 dan 45 hst

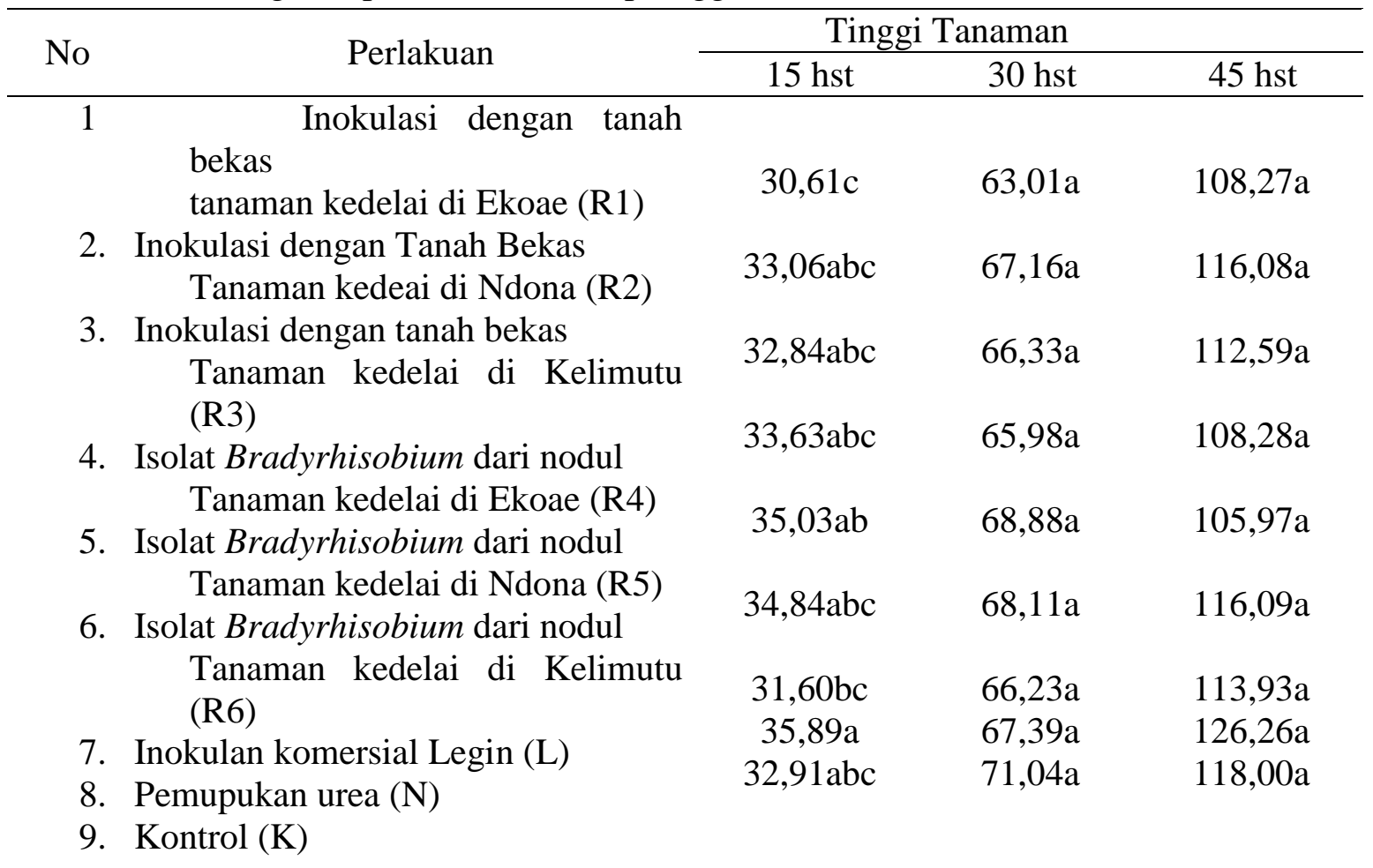
\begin{tabular}{ll}
\hline Keterangan & : Angka - angka yang diikuti dengan huruf yang sama pada kolom yang \\
& sama tidak berbeda nyata pada uji Duncan $5 \%$
\end{tabular}

4. Luas Daun Tanaman Umur 15, 30 dan 45 hst

Hasil penelitian menunjukan bahwa perlakuan inokulasi bakteri tidak memberikan pengaruh yang nyata terhadap luas dan umur 15 hst. Luas daun umur 30 dan 45 hst tertinggi pada perlakuan isolat Bradyrhisobium dari nodul tanaman kedelai di Ndona (R5) atau lebih tinggi sebesar $20,15 \%$ dan $16,05 \%$ dari luas daun pada perlakuan Kontrol (K) (Tabel 5.4) 
Tabel 5.4. Pengaruh perlakuan terhadap Luas Daun Tanaman Umur 15, 30 dan 45 hst

\begin{tabular}{|c|c|c|c|c|}
\hline \multirow{2}{*}{ No } & \multirow{2}{*}{ Perlakuan } & \multicolumn{3}{|c|}{ Tinggi Tanaman } \\
\hline & & $15 \mathrm{hst}$ & 30 hst & $45 \mathrm{hst}$ \\
\hline 1 & $\begin{array}{l}\text { Inokulasi dengan tanah bekas } \\
\text { tanaman kedelai di Ekoae (R1) }\end{array}$ & $8,88 \mathrm{a}$ & $15,74 a b$ & $20,65 a$ \\
\hline 2 & $\begin{array}{l}\text { Inokulasi dengan Tanah Bekas } \\
\text { Tanaman kedeai di Ndona (R2) }\end{array}$ & $9,35 \mathrm{a}$ & $15,92 \mathrm{ab}$ & $20,80 \mathrm{a}$ \\
\hline 3 & $\begin{array}{l}\text { Inokulasi dengan tanah bekas } \\
\text { Tanaman kedelai di Kelimutu (R3) }\end{array}$ & $9,93 \mathrm{a}$ & $15,83 \mathrm{a}$ & $20,68 \mathrm{a}$ \\
\hline 4 & $\begin{array}{l}\text { Isolat Bradyrhisobium dari nodul } \\
\text { Tanaman kedelai di Ekoae (R4) }\end{array}$ & $8,79 a$ & $16,70 \mathrm{a}$ & $21,03 \mathrm{a}$ \\
\hline 5 & $\begin{array}{l}\text { Isolat Bradyrhisobium dari nodul } \\
\text { Tanaman kedelai di Ndona (R5) }\end{array}$ & $8,95 \mathrm{a}$ & $17,43 \mathrm{a}$ & $21,53 \mathrm{a}$ \\
\hline 6 & $\begin{array}{l}\text { Isolat Bradyrhisobium dari nodul } \\
\text { Tanaman kedelai di Kelimutu (R6) }\end{array}$ & $9,99 \mathrm{a}$ & $17,14 \mathrm{a}$ & $21,14 \mathrm{a}$ \\
\hline 7 & Inokulan komersial Legin (L) & $9,32 \mathrm{a}$ & $15,66 a b$ & $18,11 \mathrm{~b}$ \\
\hline 8 & Pemupukan urea $(\mathrm{N})$ & $8,88 \mathrm{a}$ & $14,46 b$ & $19,24 \mathrm{ab}$ \\
\hline 9 & Kontrol (K) & $9,48 \mathrm{a}$ & $13,92 b$ & $18,07 b$ \\
\hline
\end{tabular}

\footnotetext{
Keterangan : Angka - angka yang diikuti dengan huruf yang sama pada kolom yang sama tidak berbeda nyata pada uji Duncan 5\%
}

5. Berat Segar dan Berat Oven Kering Tanaman

Hasil berat segar tanaman menunjukan perbedaan yang tidak nyata antara semua perlakuan (Tabel 5.5). perlakuan inokulasi Bradyrhizobium menghasilkan berat kering tanaman umur 45 hst yang tertinggi pada perlakuan dengan isolate Bradyrhizobim dari nodul tanaman kedelai di Ndona (R5) yaitu $8,47 \%$ lebih tinggi dari perlakuan inokulasi legin (L) dan $8,11 \%$ lebih tinggi dari kontrol (Tabel 5.5) 
Tabel 5.5. Pengaruh perlakuan terhadap berat segar tanaman dan kering oven tanaman umur 45 hst

\begin{tabular}{rlcc}
\hline No & \multicolumn{1}{c}{ Perlakuan } & $\begin{array}{c}\text { Berat segar } \\
\text { tanaman }\left(\mathrm{g} \mathrm{tan}^{-1}\right)\end{array}$ & $\begin{array}{c}\text { Berat kering } \\
\text { oven } \\
\text { tanaman }(\mathrm{g} \mathrm{tan} \\
\text { - }\end{array}$ \\
\hline 1 & $\begin{array}{l}\text { Inokulasi dengan tanah bekas } \\
\text { Tanaman kedelai di Ekoae (R1) }\end{array}$ & $36,87 \mathrm{a}$ & $8,92 \mathrm{bc}$ \\
2 & $\begin{array}{l}\text { Inokulasi dengan Tanah Bekas } \\
\text { Tanaman kedeai di Ndona (R2) }\end{array}$ & $36,98 \mathrm{a}$ & $9,26 \mathrm{abc}$ \\
3 & $\begin{array}{l}\text { Inokulasi dengan tanah bekas } \\
\text { Tanaman kedelai di Kelimutu (R3) }\end{array}$ & $37,14 \mathrm{a}$ & $9,14 \mathrm{abc}$ \\
4 & $\begin{array}{l}\text { Isolat Bradyrhisobium dari nodul } \\
\text { Tanaman kedelai di Ekoae (R4) }\end{array}$ & $38,06 \mathrm{a}$ & $9,48 \mathrm{ab}$ \\
5 & $\begin{array}{l}\text { Isolat Bradyrhisobium dari nodul } \\
\text { Tanaman kedelai di Ndona (R5) }\end{array}$ & $37,90 \mathrm{a}$ & $9,62 \mathrm{a}$ \\
6 & $\begin{array}{l}\text { Isolat Bradyrhisobium dari nodul } \\
\text { Tanaman kedelai di Kelimutu (R6) }\end{array}$ & $37,37 \mathrm{a}$ & $9,59 \mathrm{a}$ \\
7 & Inokulan komersial Legin (L) & $36,53 \mathrm{a}$ & $8,81 \mathrm{c}$ \\
8 & $\begin{array}{l}\text { Pemupukan urea (N) } \\
\text { Kontrol (K) }\end{array}$ & $37,16 \mathrm{a}$ & $9,38 \mathrm{abc}$ \\
& & $36,74 \mathrm{a}$ & $8,84 \mathrm{c}$ \\
\hline
\end{tabular}

Keterangan : Angka - angka yang diikuti dengan huruf yang sama pada kolom yang sama tidak berbeda nyata pada uji Duncan 5\%

6. Jumlah Total Nodul Terbentuk, Jumlah Nodul Efektif dan Efisien Pembentukan Nodul Efektif Jumlah nodul terbentuk tertinggi dengan perlakuan inokulasi komersial legin (L) yang lebih tinggi $94,24 \%$ dari jumlah nodul terendah $(\mathrm{K})$. pengaruh perlakuan pemberian inokulan komersial (L) menunjukan perbedaan yang nyata dengan perlakuan lainnya (Tabel 5.6). Jumlah nodul efektif tertinggi diperoleh pada perlakuan L yaitu lebih tinggi 95,94\% dari kontrol (K). hasil pada perlakuan L tersebut memberikan perbedaan yang nyata terhadap perlakuan lain. 
Tabel 5.6. Pengaruh perlakuan terhadap jumlah nodul terbentuk, jumlah nodul efektif dan efisiensi pembentukan nodul efektif umur 45 hst

\begin{tabular}{|c|c|c|c|c|}
\hline No & Perlakuan & $\begin{array}{c}\text { Jumlah nodul } \\
\text { terbentuk } \\
\text { (nodul } \\
\text { tanaman }^{-1} \text { ) }\end{array}$ & 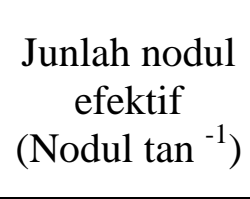 & $\begin{array}{c}\text { Presentase } \\
\text { nodul Efektif } \\
(\%)\end{array}$ \\
\hline & Inokulasi dengan tanah bekas & $7,25 b$ & & \\
\hline & tanaman kedelai di Ekoae (R1) & & $15,74 \mathrm{ab}$ & $20,65 \mathrm{a}$ \\
\hline & Inokulasi dengan Tanah Bekas & $6,25 b c$ & & \\
\hline \multirow[t]{2}{*}{2} & Tanaman kedeai di Ndona (R2) & & $15,92 \mathrm{ab}$ & $20,80 \mathrm{a}$ \\
\hline & Inokulasi dengan tanah bekas & $8,00 \mathrm{~b}$ & & \\
\hline 3 & $\begin{array}{l}\text { Tanaman kedelai di Kelimutu } \\
\text { (R3) }\end{array}$ & $6,00 \mathrm{bc}$ & $15,83 \mathrm{a}$ & $20,68 \mathrm{a}$ \\
\hline 4 & $\begin{array}{l}\text { Isolat Bradyrhisobium dari nodul } \\
\text { Tanaman kedelai di Ekoae (R4) }\end{array}$ & $5,75 b c$ & $16,70 \mathrm{a}$ & $21,03 \mathrm{a}$ \\
\hline 5 & $\begin{array}{l}\text { Isolat Bradyrhisobium dari nodul } \\
\text { Tanaman kedelai di Ndona (R5) }\end{array}$ & $5,00 \mathrm{bc}$ & $17,43 \mathrm{a}$ & $21,53 a$ \\
\hline 6 & $\begin{array}{l}\text { Isolat Bradyrhisobium dari nodul } \\
\text { Tanaman kedelai di Kelimutu }\end{array}$ & $60,75 a$ & $17,14 \mathrm{a}$ & $21,14 \mathrm{a}$ \\
\hline 7 & $(\mathrm{R} 6)$ & - & $15,66 \mathrm{ab}$ & $18,11 \mathrm{~b}$ \\
\hline 8 & Inokulan komersial Legin (L) & $3,50 \mathrm{c}$ & - & - \\
\hline 9 & $\begin{array}{l}\text { Pemupukan urea }(\mathrm{N}) \\
\text { Kontrol }(\mathrm{K})\end{array}$ & & $1,3 \mathrm{c}$ & $33,333 d$ \\
\hline
\end{tabular}

Keterangan

$\checkmark$ Angka - angka yang diikuti dengan huruf yang sama pada kolom yang sama tidak berbeda nyata pada uji Duncan 5\%

$\checkmark^{1)}$ Data ditransformasi dengan $\sqrt{(x+0,5)}$

$\checkmark$ Nodul efektif berwarna pink dan kemerahan

Efisiensi pembentukan nodul efektif menunjukan kemampuan relatif dalam membentuk nodul efektif. Perlakuan inokulasi bakteri Bradyrhizobium sp. Memberikan persentase pembentukan nodul tertinggi pada perlakuan isolat Bradyrizobium dari nodul tanaman kedelai di Ndoma (R5), terendah pada perlakuan control (K) dan perlakuan pemberian inokulan komersial Legin hanya mampu membentuk efektif yang lebih rendah (Tabel 5.6).

\subsection{Diameter Nodul dan Berat Kering} Oven Nodul

Diameter nodul efektif terbesar pada perlakuan R5 yaitu $25,57 \%$ lebih tinggi dari diameter nodul terkecil pada perlakuan dengan inokulan komersial Legin (Tabel 5.7). 
Tabel 5.7. Pengaruh perlakuan terhadap diameter, berat segar dan berat kering oven nodul

\begin{tabular}{|c|c|c|c|c|}
\hline No & Perlakuan & $\begin{array}{c}\text { Diameter } \\
\text { nodul } \\
(\mathrm{mm})\end{array}$ & $\begin{array}{c}\text { Berat segar } \\
\text { nodul } \\
\left(\mathrm{g} \mathrm{tan}^{-1}\right)\end{array}$ & $\begin{array}{l}\text { BKO nodul } \\
\text { Efektif } \\
\left(\mathrm{g} \mathrm{tan}^{-1}\right)\end{array}$ \\
\hline & Inokulasi dengan tanah bekas & $3,52 \mathrm{bc}$ & & \\
\hline 1 & tanaman kedelai di Ekoae (R1) & & $0,375 \mathrm{c}$ & $0,220 \mathrm{bc}$ \\
\hline & Inokulasi dengan Tanah Bekas & $3,28 \mathrm{bc}$ & & \\
\hline 2 & Tanaman kedeai di Ndona (R2) & & $0,395 \mathrm{c}$ & $0,285 \mathrm{ab}$ \\
\hline & Inokulasi dengan tanah bekas & $3,58 \mathrm{~b}$ & & \\
\hline & $\begin{array}{l}\text { Tanaman kedelai di Kelimutu } \\
\text { (R3) }\end{array}$ & $3,94 \mathrm{a}$ & $0,390 \mathrm{c}$ & $0,283 \mathrm{ab}$ \\
\hline & $\begin{array}{l}\text { Isolat Bradyrhisobium dari nodul } \\
\text { Tanaman kedelai di Ekoae (R4) }\end{array}$ & $3,95 \mathrm{a}$ & $0,428 \mathrm{bc}$ & $0,300 \mathrm{a}$ \\
\hline & $\begin{array}{l}\text { Isolat Bradyrhisobium dari nodul } \\
\text { Tanaman kedelai di Ndona (R5) }\end{array}$ & $3,67 \mathrm{ab}$ & $0,503 \mathrm{~b}$ & $0,335 \mathrm{a}$ \\
\hline & $\begin{array}{l}\text { Isolat Bradyrhisobium dari nodul } \\
\text { Tanaman kedelai di Kelimutu }\end{array}$ & $2,72 \mathrm{c}$ & $0,413 \mathrm{bc}$ & $0,308 \mathrm{a}$ \\
\hline 7 & $(\mathrm{R} 6)$ & - & $0,775 \mathrm{a}$ & $0,290 \mathrm{ab}$ \\
\hline 8 & Inokulan komersial Legin (L) & $2,94 \mathrm{c}$ & - & - \\
\hline 9 & $\begin{array}{l}\text { Pemupukan urea (N) } \\
\text { Kontrol (K) }\end{array}$ & & $0,220 \mathrm{~d}$ & $0,163 \mathrm{c}$ \\
\hline
\end{tabular}

\section{Keterangan : Angka-angka yang diikuti oleh huruf yang sama pada kolom yang sama tidak berbeda nyata pada ujia Duncan 5\%}

Berat segar nodul efektif tertinggi pada perlakuan dengan inokulan komcisial Legin (L) dan terendah pada kontrol (K). Diantara perlakuan yang diinokulasi bakteri Bradyrhizobiwn sp. dari Ende di dapat bahwa perlakuan isolat Bradyrhizobiwn dari nodul tanaman kedelai di Ndona (R5) lebih tinggi membentuk nodul efektif dibandingkan R1, R2, R3, R4 dan R6. Berat kering nodul efektif tertinggi pada perlakuan R5 yaitu $51,34 \%$ lebih tinggi dari berat kering nodul efektif terkecil pada perlakuan kontrol (K) (Tabel 5.7).

5.8 Kadar Nitrogen Tanaman, Nitrogen Fiksasi dan Efisiensi Simbiosis
Hasil penelitian menunjukkan kadar nitrogen tanaman tertinggi pada perlakuan pemupukan urea $(\mathrm{N})$. Pada perlakuan inokulasi bakteri Bradyrhizobium sp. menghasilkan kadar nitrogen tanaman tertinggi pada perlakuan isolat Bradyrhizobium dari nodul tanaman kedelai di Ndona (R5) yang berbeda nyata dengan R1, R2, R3, R4, R6, L dan K. Kadar nitrogen tanaman terkecil pada kontrol $(\mathrm{K})$ yaitu 1,295\% (Tabel 5.8).

$\mathrm{N}$ fiksasi tertinggi pada perlakuan R5 dan terendah pada perlakuan inokulasi Legin (Tabel 5.8). Efisiensi pembentukan nodul oleh bakteri Bradyrhizobiwn sp. terhadap kontrol tertinggi diperoleh R5 yang berbeda nyata dengan perlakuan RL R2, R3， R4， R6 dan L (Tabel 5.8). 
Tabel 5.8. Pengaruh perlakuan terhadap Kadar Nitrogen Tanaman, Nitrogen Fiksasi dan Efisiensi Simbiosis

\begin{tabular}{|c|c|c|c|c|}
\hline No & Perlakuan & $\begin{array}{c}\text { Kadar N } \\
\text { tanaman } \\
(\%)\end{array}$ & $\begin{array}{c}\text { N Fiksasi } \\
(\%)\end{array}$ & $\begin{array}{c}\text { Efisiensi } \\
\text { Simbiosis } \\
(\%)\end{array}$ \\
\hline & Inokulasi dengan tanah bekas & $1,470 \mathrm{~b}$ & & \\
\hline 1 & tanaman kedelai di Ekoae (R1) & & $0,175 \mathrm{ab}$ & $113,757 \mathrm{~b}$ \\
\hline & Inokulasi dengan Tanah Bekas & $1,503 \mathrm{~b}$ & & \\
\hline 2 & Tanaman kedeai di Ndona (R2) & & $0,208 \mathrm{ab}$ & $116,358 \mathrm{~b}$ \\
\hline & Inokulasi dengan tanah bekas & $1,398 \mathrm{~b}$ & & \\
\hline 3 & $\begin{array}{l}\text { Tanaman kedelai di Kelimutu } \\
\text { (R3) }\end{array}$ & $1,543 \mathrm{~b}$ & $0,103 \mathrm{~b}$ & $108,635 \mathrm{~b}$ \\
\hline 4 & $\begin{array}{l}\text { Isolat Bradyrhisobium dari nodul } \\
\text { Tanaman kedelai di Ekoae (R4) }\end{array}$ & $1,815 \mathrm{a}$ & $0,248 a b$ & $119,464 b$ \\
\hline 5 & $\begin{array}{l}\text { Isolat Bradyrhisobium dari nodul } \\
\text { Tanaman kedelai di Ndona (R5) }\end{array}$ & $1,540 \mathrm{~b}$ & $0,520 \mathrm{a}$ & $140,833 \mathrm{a}$ \\
\hline & Isolat Bradyrhisobium dari nodul & & $0,245 \mathrm{ab}$ & $119,612 b$ \\
\hline 7 & $\begin{array}{l}\text { Tanaman kedelal di Kelimutu } \\
\text { (R6) }\end{array}$ & $\begin{array}{l}1,3 / 8 \mathrm{~b} \\
1,998 \mathrm{a}\end{array}$ & $0,083 \mathrm{~b}$ & $107,185 \mathrm{~b}$ \\
\hline 8 & Inokulan komersial Legin (L) & $1,295 \mathrm{~b}$ & - & - \\
\hline 9 & $\begin{array}{l}\text { Pemupukan urea }(\mathrm{N}) \\
\text { Kontrol }(\mathrm{K})\end{array}$ & & - & - \\
\hline
\end{tabular}
Keterangan
$\checkmark$ Angka - angka yang diikuti dengan huruf yang sama pada kolom yang sama tidak berbeda nyata pada uji Duncan 5\%
$\checkmark^{1)}$ Data ditransformasi dengan $\sqrt{(x+0,5)}$

\section{SIMPULAN}

Dari analisis yang telah dipaparkan terdahulu dapat disimpulkan sebagai berikut

1. Tanah-tanah dari Ekoae, Ndona, dan Kelimutu telah mengandung bakteri Bradyrhizobium yang tinggi. Isolat dari nodul tanaman kedelai di Ndona (R5) paling banyak mengandung bakteri Bradyrhizobium sp.

2. Isolat dari nodul tanaman kedelai di Ndona (R5) paling efisien membentuk nodul efektif yaitu $82,26 \%$

3. Isolat dari nodul tanaman kedelai di Ndona (R5) paling tinggi memfiksasi $\mathrm{N}$ yaitu 0,52 $\%$

\section{UCAPAN TERIMA KASIH}

Pada kesempatan ini penulis ingin mengucapkan terima kasih kepada semua pihak yang telah membantu dengan caranya masing-masing dalam melengkapi tulisan ini.

\section{DAFTAR PUSTAKA}

Airtur, M.M. 2004. Pengaruh Dosis Mikoriza dan Tingkat Kadar Air Tanah Terhadap Efisiensi Penggunaan Air, Serapan P dan 
Hasil Kedelai (Glycine max (L.) merr). Pada Tanah Alfisol. (Tesis) Denpasar: Universitas Udayana

BPS Kabupaten Ende. 2008. Potensi Komoditi Industri Kecil dan Menengah. Avaliable from: URL:

http://www.endekab.go.id/info\% 20Harga\%20pasar\%2010\%20ap ril\%008.html

Freire, J. R.J. 1984. Important limiting Factor in soil. In : Alexander, M,. Editor. Biological nitrogen fixation : ecology, technology, and physiologi. Nem York : plenm press. P. $51-72$

Gray, T.R.G., Williams, S.T. 1971 soil microorganisms. London : longman group limited.

Gomez, K.A., Gomez, A.A. 2007. Prosedur Statistik Untuk Penelitian Pertanian. Edisi ke 2. Jakarta: Universitas Indonesia.

Havlin, J.L., Beaton, J.D., Tisdale, S.L., Nelson, W.L. 1999. Soil Fertility and Fertilizer. An Introduction to Nutrient Management. $6^{\text {th }}$ Ed. New Jersey : Prentice Hall.

Islami, T., Utomo, W.H. 1995. Hubungan Tanah, Air dan Tanaman. Semarang: IKIP Press.

Jutomo. 1981. Prospek Inokulasi pada Peningkatan Produksi Kedelai dan Leguminosa Lainnya. Yogyakarta: Universitas Gajah Mada.

Muksin, L.K. 2006. Pengaruh Pemakaian Inokulan Komersial,
Biakan Murni Rhizobium sp. dan Tanah Bekas Kedelai Terhadap Pembentukan Nodul dan Hasil Kedelai (Glycine max (L.) Merril). (Tesis) Denpasar : Universitas Udayana.

Ogutcu, H., Algur, O.F., Elkoca, E., Kantar, F. 2008. The Determination of Symbiotic Effectiveness of Rhizobium Strains Isolated from Wild Chickpeas Co;;ected from High Altitudes in Erzurum. Turk. J. Agric, Turkey. 32 : 241-248.

Purwaningsih S. 2005b. Seleksi Biak Rhizobium dari Wonogiri, Jawa Tengah Terhadap Pertumbuhan Kedelai (Glycine max L.) pada Media Pasir Steril di Rumah Kaca. J. Biodiversitas, Bogor. $168-171$.

Rao, N.S.S. 1994. Mikrobiologi tanah dan pertumbuhan tanaman. Jakarta : Universitas Indonesia. Hal. 143 - 191

Rhijin, P.V., Vanderleyden, J. 1995. The Rhizobium - Palnt Symbiosis. Mikrobiological Reviews, Amerika. 59 : 124 142

Simanungkalit, R.DM..,Dkk. 2006. Bakteri Penambat Nitrogen. Dalam : Simanungkalit, R.D.M., Dkk. Editor . Pupuk Organik dan Pupuk Hayati. Bogor : Balai Besar Penelitian Sumberdaya Lahan Pertanian. $113-140$. 